\title{
RISK CATEGORIES AND RISK MANAGEMENT PROCESSES IN NONPROFIT ORGANIZATIONS
}

\author{
Jarosław DOMAŃSKI \\ Warsaw University of Technology, Faculty of Management, Warsaw, Poland \\ e-mail: j.domanski@wz.pw.edu.pl
}

\begin{abstract}
The article addresses risk management in nonprofit organizations. This topical issue appears not to have been adequately studied by researchers to date. There are several questions the author of this paper attempts to answer: What are the risk categories faced by nonprofit organizations in their daily operations? Do Polish nonprofit organizations take any measures in the area of strategic risk management? A contribution is made to the theory of management of nonprofit organizations by making an overview of existing literature on the subject, identifying a research gap, proposing concepts that attempt to fill the gap, and recommending areas for future study. A comprehensive list of risks faced by nonprofit organizations in their daily operations has been developed and validated for further application. The empirical material comes from a study based on a national random sample of 235 nonprofit organizations.
\end{abstract}

Keywords: risk management, nonprofit organizations, strategic management, risk management process.

\section{1}

\section{Introduction}

A review of the latest writings on nonprofit management and risk management reveals significant gap in research on risk in the third sector. There are many different kinds of research approaches to these issues, but it seems that a comprehensive theory about risk management in the third sector may be missing. Most of the studies have concentrated on testing fragmentary hypotheses on specific risk categories (Martinez, 2003; Wymer and Samu, 2003; Clary, 1997; Jackson, 2008; Greenlee and Tuckman, 2007; Kearns, 2007; Yetman, 2007; Young, 2007; Christensen et al., 2009) or on organizations operating in specific fields and related risks (Fast, 2007; Sollis, 1995; Mu-Sheng Chang, 2008, Eugenio, 2008; Mu-Sheng Chang, 2008) or on available tools or strategies of risk management (Yan, 2009; Lehn, 2008; Mallin, Finkle, 2007; Sharp, Brock, 2012; Stewart, Trussel, 2006). The belief that there is research gap in this field is shared by researchers such as West and Sargeant and they propose applying existing risk management theory from the commercial sector to nonprofit organizations (West and Sargeant, 2004). This proposition may not be a correct one, however. Risk management in nonprofit organizations is a more complex process because of factors such as a relatively high number of uninsurable risks (Head \& Herman, 2002). Most research papers concentrate on identifying ways how nonprofits can minimize the risks that they face, rather than on how it can be managed by them. Research in this field is by all means a pioneering effort (Young, 2009).

The main goal of this article is to fill the research gap as much as possible by presenting the results and conclusions of a study on risk management in the third sector.

The first research question of this study project is: What are the risk categories faced by nonprofit organizations? A comprehensive and structured list of risks relevant to nonprofit organizations has been developed. To supplement the main questions, nonprofit organizations were asked about their perception of probability of the various risks and their impact on the organizations. Nonprofit organizations can easily use the risk list in their daily risk management.

The second question was whether Polish nonprofit organizations implemented any strategic risk management measures. If so, what are these measures and are they in line with theoretical models described in the literature? The strategic risk management 
model proposed by Head and Herman (2002) was reviewed to answer the above questions. ${ }^{1}$

This article is organized around the research questions. The first part presents the adopted research methodology. The second part looks at the main risk categories. An overview of existing literature has generated a list of risks faced by nonprofit organizations in their operations. Findings of a dedicated research that respond to the research question are presented. The third part validates the proposed strategic risk management model. Finally, the article presents conclusions and recommendations.

\section{Research Method}

The Polish nonprofit sector was used as the general population, and the number of organizations is estimated at approximately 80,000, mostly foundations and associations. The two-year research study conducted by the Klon/Jawor Association reveals that there were over 58,000 associations and more than 9,000 foundations at the end of Q1 2008 (Gumkowska \& Herbst, 2008). All nongovernmental organizations that operate in Poland with the public benefit organizations status have been included in the project sample. Such organizations are required to have a specific structure in place; they tend to operate on a wider scale, offer financial transparency, and meet other requirements under the Law on Public Benefit and Volunteering. This sample leaves out smaller organizations, ones which do not operate on a regular basis, that are registered but inactive - in other words, organizations for which implementing a strategic management system is not an immediate necessity. This sample design has been used by other Polish researchers in this area (Domański, 2012; Krzelowska, 2008). The database of such organizations is published by the Ministry of Labor and Social Policy on its website. In December 2010, the database featured 6,690 records of public benefit organizations.

A sample of 235 was selected for the study. The size of the sample was a balancing act between statistical

\footnotetext{
${ }^{1}$ Considerations and research results were previously published in Domański, J. (2014). Zarzqdzanie ryzykiem w organizacjach non profit. Warszawa: Wolters Kluwer.
}

representativeness and a limited budget available for the study.

The random sample was selected from the whole population on an individual basis without replacement. This method samples an individual entity from the entire population of organizations. Then, the entity is removed from the database to prevent reselection. As the representativeness of the sample is a function of the sampling frame, it can be postulated that the sample selected for this study is fully representative for all public benefit organizations in Poland.

A guided interview was conducted with top leaders of the selected organizations. Directing the questionnaire exclusively at them allowed ensuring a greater credibility of obtained replies because of the fact that they were often the only competent representatives of the examined organization. This directly follows the characteristics of Polish nonprofit organizations that rarely employ qualified personnel in lower-level management.

There were three phases: (1) Desk research to identify the list of public benefit organizations; (2) CATI (Computer Assisted Telephone Interview) to identify the target individual in the organization and to seek permission to take part in the study and obtain the email address to which the link with the questionnaire was to be sent; (3) CAWI (Computer Assisted Web Interview) or the core part of the study where respondents filled in a web-based questionnaire.

The database was created in Q3 2010 based on data available from https://bopp.pozytek.gov.pl/szukaj.do with the details of all public benefit organizations which filed their financial statement for 2009 or 2008 .

The second phase of the project took place in January 2011. Top leaders of the sampled organizations were targeted to make sure that they personally filled out the questionnaire. Six hundred telephone numbers were sampled from the entire population (draw subsidiaries, unlimited, individual).

The third phase took place from February to May 2011 and continued until the target sample of 235 filled questionnaires was completed. Up to five reminders were sent during the phase to encourage starting or completing the questionnaire filling pro- 
cess. The application of such methodology in the analysis of questionnaire answers allowed not taking into account not fully completed questionnaires and cases of total refusal to answer.

\section{$3 \quad$ Risk Categories}

There is no comprehensive description in international research literature of risks faced by nongovernmental organizations. Authors have mostly alluded to the risk of partnership, co-operation, or alliance (Martínez, 2003; Sollis, 1995; Waśkowski, 2008; Wymer Jr., Samu, 2003); reputation risk (Clary, 1997; Iwankiewicz-Rak, 2006; Jackson, 2008); and financial risk (Bowman, Keating, Hager, 2007; Greenlee, Tuckman, 2007; Kearns, 2007; Trussel, Patrick, 2009; Yan, Denison, Butler, 2009; Yetman, 2007; Young, 2007). Other less explored risk categories faced by nonprofit organizations include asset risk (Duncan, 2008; Pike, Roos, Marr, 2005); legal risk, including risk of loss, litigation risk, risk of inadequate legal interpretation, compliance risk, reputation risk (Zapadka, 2007); grant risk (Tyrakowski, 2007); risk of mission drift in a highincome scenario (Christensen, Clerkin, Nesbit, Paarlberg, 2009); risk of staff death, especially if the organization operate in armed conflict zones (Fast, 2007); organization, personal, and time (Mitchell, 1995); and advertising risk (West, Sargeant, 2004).

Risks associated with partnerships and alliances are an important area of research. Martinez (2003) analyzed such forms of collaboration between nongovernmental organizations, and he pointed to risks that occur before, during, and after alliances. He stressed that alliances with the commercial sector may create certain risks for nonprofit organizations such as that of losing sight of the core mission. A significant risk emerges when a partner of the nonprofit organization engages in unethical activities and has been stigmatized by the public (Wymer Jr., Samu, 2003).

Collaboration, especially with governmental organizations, may force a nonprofit organization to offer excessive concessions and ultimately lose independence (Sollis, 1995). Another threat is the gradually developing overdependence of an organization on one strong partner who may demand more privileges in the future (Waśkowski, 2007).

Another important risk category listed by researchers as a relevant one for nonprofit organizations is the reputation risk. This may include any events related to the nonprofit organization that may lead to bad publicity. This risk may be related to non-action, for example, "not enough commitment shown by the non-governmental organization to keep the environment informed (...) may compromise public trust and support" (Iwankiewicz-Rak, 2006).

Clary listed a number of activities that nonprofit organizations may engage in to mitigate the reputation risk, which if they do not pursue would increase the reputation risk. They may include spending the grants in line with donor instructions; developing written internal procedures, principles and requirements, legal compliance, sound accounting practices; and spending approval discipline (Clary, 1997). Jackson pointed out to the role of external auditors who may help the organization protect itself against fraud that may jeopardize its reputation (Jackson, 2008).

Further, researchers have addressed the impact of financial risks on nonprofit organizations. Greenlee and Tuckman (2007) stressed the central role of risk in the process of ensuring the financial health of the organization. Kearns (2007) analyzed the structure of the revenue portfolio and observed that risk should be the central point of reference in decisions in this area. Yetman argued that risk may be associated with the indebtedness of a nonprofit organization. Donors may be unwilling to support an organization without the assurance that grants will not be used to repay past liabilities (Yetman, 2007).

Special funds and investment projects play a special role in managing financial risks of non-governmental organizations (Bowman, et al., 2007). Yan et al. (2009) stated that financial risk is a factor that is exceptionally difficult to control. Control is easier when factors affecting the financial risk are identified. Trussel and Patrick (2009) have gone through this process with respect to hospitals, and they listed the following factors: structural factors, financial factors, payer mix, risk of utilization, and market factors. Financial risk mitigation measures include: diversification of revenue portfolio, sources, 
and categories (Young, 2007); the use of selfinsurance (Mu-Sheng Chang, 2008); implementation of a fund-raising plan (Tyminshi, 1998); and use of financial derivatives such as interest rate swaps (Stewart, Trussel, 2006) and derivatives (Stewart, Owhoso, 2004).

This overview of literature leads to several important conclusions. First, there has been some interest among researchers in risk in nonprofit organizations. Second, no attempts have been made to propose a uniform and coherent classification of risk categories in the third sector. Authors usually concentrate on selected types of risk, mostly on the most prevalent ones (partnership or financial risk), and explore specific types of organizations (mostly in the health sector). Third, there is apparently a lack of representative empirical studies looking at risk categories in the third sector in a national context, especially in Poland. In addition, the characteristics of Polish Third Sector explicitly show that it goes through its initial stage of development which is typical of the countries of Central and Eastern Europe and, at the same time, is separated from the sectors in countries such as the United States, the United Kingdom, and Germany.

In the light of the above, the classification of risk categories in nonprofit organization and the research findings presented in this article may be seen as a relevant and original contribution to the body of knowledge on risk management and general management in nonprofit organizations.

Table 1 summarizes all key risk categories faced by nonprofit organizations, as proposed by the author.

The research project was largely concentrated on validating the risk categories. Respondents were asked to estimate the likelihood of these risks materializing on a scale of unlikely, possible, 50/50, likely, and nearly certain and to assign the force of impact of each risk on the organization on a scale of insignificant, minor, moderate, major, and critical.

Table 1. Risk Categories in Nonprofit Organizations

\begin{tabular}{|c|c|c|c|c|c|c|c|c|c|c|c|}
\hline \multirow{3}{*}{$\begin{array}{c}\text { Risks } \\
\text { in Nonprofit } \\
\text { Organizations }\end{array}$} & \multicolumn{5}{|c|}{ Probability of Occurrence } & \multicolumn{6}{|c|}{ Impact on Organization } \\
\hline & $\begin{array}{c}\text { Unlike- } \\
\text { ly }\end{array}$ & Possible & $50 / 50$ & Likely & $\begin{array}{l}\text { Nearly } \\
\text { Certain }\end{array}$ & $\begin{array}{c}\text { Insignif- } \\
\text { icant }\end{array}$ & Minor & $\begin{array}{l}\text { Moder- } \\
\text { ate }\end{array}$ & Major & Critical & $\begin{array}{c}\text { Don't } \\
\text { know/ } \\
\text { hard to } \\
\text { tell } \\
\end{array}$ \\
\hline & $(\%)$ & $(\%)$ & $(\%)$ & $(\%)$ & $(\%)$ & $(\%)$ & $(\%)$ & $(\%)$ & $(\%)$ & $(\%)$ & $(\%)$ \\
\hline \multicolumn{12}{|c|}{ Category - Management (Recognized by $39.0 \%)$} \\
\hline $\begin{array}{l}\text { Inadequate organization } \\
\text { structure }\end{array}$ & 35.7 & 40.0 & 11.1 & 11.1 & 2.1 & 21.3 & 37.9 & 24.7 & 15.3 & 0.9 & 0.0 \\
\hline $\begin{array}{l}\text { Management lacks ade- } \\
\text { quate experience or not } \\
\text { well organized }\end{array}$ & 51.1 & 15.7 & 17.4 & 13.2 & 2.6 & 17.9 & 17.0 & 31.1 & 26.4 & 7.7 & 0.0 \\
\hline $\begin{array}{l}\text { Management dominated } \\
\text { by individual leaders }\end{array}$ & 37.4 & 26.8 & 11.1 & 17.9 & 6.8 & 13.6 & 27.2 & 34.0 & 20.9 & 4.3 & 0.0 \\
\hline $\begin{array}{l}\text { Resignation of key per- } \\
\text { sonnel }\end{array}$ & 31.5 & 48.9 & 4.3 & 11.1 & 4.3 & 6.8 & 26.0 & 22.6 & 39.6 & 5.1 & 0.0 \\
\hline Conflict of interest & 51.5 & 33.6 & 8.5 & 2.1 & 4.3 & 28.5 & 17.0 & 16.6 & 27.7 & 10.2 & 0.0 \\
\hline $\begin{array}{l}\text { Ineffective communica- } \\
\text { tion system }\end{array}$ & 22.1 & 44.7 & 17.9 & 11.1 & 4.3 & 11.1 & 28.5 & 46.4 & 11.5 & 2.1 & 0.4 \\
\hline $\begin{array}{l}\text { No direction, strategy, } \\
\text { and plans }\end{array}$ & 51.1 & 24.3 & 11.1 & 11.1 & 2.6 & 23.8 & 22.1 & 33.6 & 15.3 & 5.1 & 0.0 \\
\hline
\end{tabular}


Table 1. Risk Categories in Nonprofit Organizations, cont.

\begin{tabular}{|c|c|c|c|c|c|c|c|c|c|c|c|}
\hline \multirow{3}{*}{$\begin{array}{c}\text { Risks } \\
\text { in Nonprofit } \\
\text { Organization }\end{array}$} & \multicolumn{5}{|c|}{ Probability of Occurrence } & \multicolumn{6}{|c|}{ Impact on Organization } \\
\hline & $\begin{array}{c}\text { Unlike- } \\
\text { ly }\end{array}$ & $\begin{array}{l}\text { Possi- } \\
\text { ble }\end{array}$ & $50 / 50$ & Likely & $\begin{array}{l}\text { Nearly } \\
\text { Certain }\end{array}$ & $\begin{array}{c}\text { Insig- } \\
\text { nificant }\end{array}$ & Minor & $\begin{array}{c}\text { Moder- } \\
\text { ate }\end{array}$ & Major & Critical & $\begin{array}{c}\text { Don't } \\
\text { know/ } \\
\text { hard to } \\
\text { tell }\end{array}$ \\
\hline & $(\%)$ & $(\%)$ & $(\%)$ & $(\%)$ & $(\%)$ & $(\%)$ & $(\%)$ & $(\%)$ & $(\%)$ & $(\%)$ & $(\%)$ \\
\hline \multicolumn{12}{|c|}{ Category - Operational Risk (Recognized by $54.6 \%$ ) } \\
\hline Not enough beneficiaries & 44.7 & 31.1 & 11.1 & 8.9 & 4.3 & 13.2 & 13.2 & 21.7 & 31.5 & 20.4 & 0.0 \\
\hline $\begin{array}{l}\text { Not enough well-trained } \\
\text { personnel }\end{array}$ & 15.7 & 62.1 & 13.2 & 8.9 & 0.0 & 6.8 & 25.1 & 26.0 & 37.4 & 4.3 & 0.4 \\
\hline $\begin{array}{l}\text { Uncertainty about securi- } \\
\text { ty of assets }\end{array}$ & 31.1 & 28.9 & 24.7 & 11.1 & 4.3 & 14.0 & 14.5 & 28.9 & 35.7 & 5.5 & 1.3 \\
\hline $\begin{array}{l}\text { Competition from other } \\
\text { organizations }\end{array}$ & 17.9 & 37.9 & 17.9 & 24.3 & 2.1 & 15.7 & 36.2 & 35.7 & 11.9 & 0.4 & 0.0 \\
\hline $\begin{array}{l}\text { Dependence on suppliers } \\
\text { (their strong bargaining } \\
\text { power) }\end{array}$ & 37.9 & 48.9 & 8.9 & 4.3 & 0.0 & 31.1 & 22.1 & 33.2 & 10.6 & 3.0 & 0.0 \\
\hline $\begin{array}{l}\text { Ineffective fundraising } \\
\text { system }\end{array}$ & 4.3 & 40.4 & 24.3 & 17.9 & 13.2 & 6.4 & 19.1 & 15.7 & 42.6 & 14.0 & 2.1 \\
\hline $\begin{array}{l}\text { Lack of formalized pro- } \\
\text { cedures }\end{array}$ & 34.0 & 44.3 & 13.2 & 4.3 & 4.3 & 17.4 & 15.3 & 37.4 & 28.1 & 1.7 & 0.0 \\
\hline $\begin{array}{l}\text { Inefficient and ineffective } \\
\text { IT system }\end{array}$ & 32.8 & 46.8 & 8.9 & 8.9 & 2.6 & 15.7 & 26.0 & 37.9 & 20.0 & 0.0 & 0.4 \\
\hline $\begin{array}{l}\text { Implementing activities } \\
\text { in a dangerous environ- } \\
\text { ment }\end{array}$ & 80.0 & 15.7 & 0.4 & 0.0 & 3.8 & 31.1 & 16.2 & 8.9 & 17.0 & 25.1 & 1.7 \\
\hline $\begin{array}{l}\text { Natural disaster, fire, } \\
\text { flood, theft }\end{array}$ & 28.9 & 51.1 & 8.9 & 6.8 & 4.3 & 17.9 & 20.4 & 11.5 & 24.3 & 24.7 & 1.3 \\
\hline $\begin{array}{l}\text { Deviation from core mis- } \\
\text { sion "in search of" fund- } \\
\text { ing sources }\end{array}$ & 46.8 & 37.4 & 8.9 & 6.8 & 0.0 & 26.4 & 11.5 & 28.1 & 28.5 & 4.7 & 0.9 \\
\hline \multicolumn{12}{|c|}{ Category - Financial Risk (Recognized by 76.6\%) } \\
\hline $\begin{array}{l}\text { Inaccurate and/or insuffi- } \\
\text { cient financial infor- } \\
\text { mation }\end{array}$ & 51.1 & 37.9 & 8.9 & 2.1 & 0.0 & 13.6 & 24.3 & 26.8 & 32.8 & 2.1 & 0.4 \\
\hline $\begin{array}{l}\text { No financial planning } \\
\text { (budgeting) }\end{array}$ & 55.7 & 31.1 & 8.9 & 4.3 & 0.0 & 17.9 & 22.1 & 17.9 & 32.3 & 8.1 & 1.7 \\
\hline $\begin{array}{l}\text { Lack of financial liquidi- } \\
\text { ty }\end{array}$ & 15.7 & 46.8 & 13.2 & 17.9 & 6.4 & 11.1 & 6.8 & 13.6 & 51.5 & 17.0 & 0.0 \\
\hline $\begin{array}{l}\text { Poor pricing policy (e.g., } \\
\text { overpriced activities in } \\
\text { grant applications) }\end{array}$ & 46.8 & 37.9 & 11.5 & 2.6 & 1.3 & 17.9 & 17.4 & 26.4 & 34.9 & 2.6 & 0.9 \\
\hline Excessive indebtedness & 68.5 & 25.1 & 1.7 & 4.7 & 0.0 & 24.3 & 4.3 & 8.5 & 39.6 & 23.0 & 0.4 \\
\hline
\end{tabular}


Table 1. Risk Categories in Nonprofit Organizations, cont.

\begin{tabular}{|c|c|c|c|c|c|c|c|c|c|c|c|}
\hline \multirow{3}{*}{$\begin{array}{c}\text { Risks } \\
\text { in Nonprofit } \\
\text { Organization }\end{array}$} & \multicolumn{5}{|c|}{ Probability of Occurrence } & \multicolumn{6}{|c|}{ Impact on Organization } \\
\hline & $\begin{array}{c}\text { Unlike- } \\
\text { ly }\end{array}$ & $\begin{array}{l}\text { Possi- } \\
\text { ble }\end{array}$ & $50 / 50$ & Likely & $\begin{array}{l}\text { Nearly } \\
\text { Certain }\end{array}$ & $\begin{array}{l}\text { Insig- } \\
\text { nificant }\end{array}$ & Minor & $\begin{array}{c}\text { Moder- } \\
\text { ate }\end{array}$ & Major & Critical & $\begin{array}{l}\text { Don't } \\
\text { know/ } \\
\text { hard to } \\
\text { tell }\end{array}$ \\
\hline & $(\%)$ & $(\%)$ & $(\%)$ & $(\%)$ & $(\%)$ & $(\%)$ & $(\%)$ & $(\%)$ & $(\%)$ & $(\%)$ & $(\%)$ \\
\hline FX losses & 73.6 & 23.4 & 0.9 & 0.4 & 1.7 & 40.4 & 26.4 & 11.5 & 17.4 & 3.4 & 0.9 \\
\hline Financial fraud & 75.3 & 19.6 & 0.9 & 0.0 & 4.3 & 20.0 & 8.5 & 16.2 & 30.6 & 22.1 & 2.6 \\
\hline High transactional costs & 44.7 & 46.8 & 6.0 & 2.6 & 0.0 & 24.3 & 20.4 & 24.3 & 26.4 & 4.3 & 0.4 \\
\hline $\begin{array}{l}\text { Inadequate maintenance } \\
\text { of long-term sources of } \\
\text { funding }\end{array}$ & 42.1 & 46.8 & 4.3 & 4.7 & 2.1 & 8.9 & 13.6 & 24.3 & 42.1 & 9.4 & 1.7 \\
\hline $\begin{array}{l}\text { Inadequate reserves and } \\
\text { cash flow }\end{array}$ & 20.0 & 46.8 & 15.3 & 13.2 & 4.7 & 4.3 & 15.3 & 28.9 & 39.6 & 11.1 & 0.9 \\
\hline $\begin{array}{l}\text { Dependence on a low } \\
\text { number of revenue } \\
\text { sources }\end{array}$ & 15.3 & 35.7 & 15.3 & 24.3 & 9.4 & 2.6 & 22.1 & 24.7 & 43.0 & 6.4 & 1.3 \\
\hline $\begin{array}{l}\text { Inadequate investment } \\
\text { policy }\end{array}$ & 37.9 & 24.7 & 15.3 & 17.4 & 4.7 & 22.1 & 21.7 & 28.9 & 24.7 & 2.6 & 0.0 \\
\hline $\begin{array}{l}\text { Inadequate insurance } \\
\text { coverage }\end{array}$ & 44.3 & 31.9 & 17.0 & 6.8 & 0.0 & 17.9 & 31.1 & 24.7 & 23.8 & 2.6 & 0.0 \\
\hline $\begin{array}{l}\text { Funds used against the } \\
\text { intent of donor/grantor }\end{array}$ & 84.3 & 8.9 & 4.3 & 2.6 & 0.0 & 22.1 & 6.8 & 15.7 & 30.2 & 23.0 & 2.1 \\
\hline \multicolumn{12}{|c|}{ Category - External Risk (Recognized by $24.1 \%$ ) } \\
\hline $\begin{array}{l}\text { Low recognition and } \\
\text { weak reputation of organ- } \\
\text { ization }\end{array}$ & 55.7 & 35.7 & 6.4 & 2.1 & 0.0 & 8.5 & 22.1 & 26.4 & 40.0 & 2.6 & 0.4 \\
\hline Unfavorable publicity & 41.7 & 46.8 & 11.1 & 0.4 & 0.0 & 13.6 & 11.1 & 20.4 & 44.3 & 8.9 & 1.7 \\
\hline $\begin{array}{l}\text { Demographic change } \\
\text { causing significant in- } \\
\text { crease/decrease in bene- } \\
\text { ficiary numbers }\end{array}$ & 44.3 & 42.1 & 6.4 & 7.2 & 0.0 & 13.2 & 26.4 & 33.2 & 24.3 & 2.1 & 0.9 \\
\hline $\begin{array}{l}\text { Turbulent economic/ } \\
\text { political environment }\end{array}$ & 11.1 & 60.0 & 13.2 & 13.6 & 2.1 & 6.4 & 27.2 & 40.4 & 20.0 & 4.3 & 1.7 \\
\hline $\begin{array}{l}\text { Change in government } \\
\text { policy }\end{array}$ & 11.5 & 42.1 & 20.4 & 17.4 & 8.5 & 6.8 & 21.3 & 33.2 & 28.1 & 8.9 & 1.7 \\
\hline
\end{tabular}


Table 1. Risk Categories in Nonprofit Organizations, cont.

\begin{tabular}{|c|c|c|c|c|c|c|c|c|c|c|c|}
\hline \multirow{3}{*}{$\begin{array}{c}\text { Risks } \\
\text { in Nonprofit } \\
\text { Organization }\end{array}$} & \multicolumn{5}{|c|}{ Probability of Occurrence } & \multicolumn{6}{|c|}{ Impact on Organization } \\
\hline & $\begin{array}{l}\text { Un- } \\
\text { likely }\end{array}$ & $\begin{array}{l}\text { Pos- } \\
\text { sible }\end{array}$ & $50 / 50$ & $\begin{array}{l}\text { Like- } \\
\text { ly }\end{array}$ & $\begin{array}{l}\text { Near- } \\
\text { ly } \\
\text { Cer- } \\
\text { tain }\end{array}$ & $\begin{array}{l}\text { Insig- } \\
\text { nifi- } \\
\text { cant }\end{array}$ & Minor & $\begin{array}{l}\text { Mod- } \\
\text { erate }\end{array}$ & Major & $\begin{array}{l}\text { Criti- } \\
\text { cal }\end{array}$ & $\begin{array}{l}\text { Don't } \\
\text { know/ } \\
\text { hard } \\
\text { to tell } \\
\end{array}$ \\
\hline & $(\%)$ & $(\%)$ & $(\%)$ & $(\%)$ & $(\%)$ & $(\%)$ & $(\%)$ & $(\%)$ & $(\%)$ & $(\%)$ & $(\%)$ \\
\hline \multicolumn{12}{|c|}{ Category - Legal Risk (Recognized by 33.3\%) } \\
\hline Active abuse of trust & 61.7 & 28.9 & 8.9 & 0.4 & 0.0 & 13.2 & 19.6 & 28.1 & 30.6 & 6.4 & 2.1 \\
\hline $\begin{array}{l}\text { Low level of knowledge } \\
\text { of labor law }\end{array}$ & 49.8 & 38.3 & 6.4 & 0.9 & 4.7 & 13.2 & 37.9 & 22.6 & 24.7 & 1.7 & 0.0 \\
\hline $\begin{array}{l}\text { Low level of understand- } \\
\text { ing of laws and regula- } \\
\text { tions regarding fields } \\
\text { of operation }\end{array}$ & 54.5 & 30.6 & 5.1 & 2.6 & 7.2 & 15.3 & 22.6 & 36.2 & 22.1 & 3.0 & 0.9 \\
\hline $\begin{array}{l}\text { Incorrect interpretation } \\
\text { of law }\end{array}$ & 37.0 & 48.5 & 3.0 & 5.1 & 6.4 & 15.3 & 15.3 & 24.7 & 34.0 & 8.1 & 2.6 \\
\hline Litigation & 62.6 & 31.1 & 1.7 & 2.6 & 2.1 & 15.7 & 19.1 & 23.8 & 31.5 & 8.5 & 1.3 \\
\hline $\begin{array}{l}\text { Possibly subject to taxa- } \\
\text { tion }\end{array}$ & 28.1 & 51.9 & 13.6 & 6.4 & 0.0 & 6.4 & 25.1 & 31.5 & 31.9 & 4.7 & 0.4 \\
\hline \multicolumn{12}{|c|}{ Category - Collaboration Risk (Recognized by 51.1\%) } \\
\hline Loss of identity & 70.2 & 19.6 & 8.9 & 1.3 & 0.0 & 11.1 & 8.9 & 22.1 & 46.4 & 10.6 & 0.9 \\
\hline $\begin{array}{l}\text { Loss of reputation as a } \\
\text { result of partner's unethi- } \\
\text { cal conduct }\end{array}$ & 48.9 & 36.2 & 9.4 & 5.1 & 0.4 & 8.5 & 2.1 & 34.9 & 46.4 & 6.8 & 1.3 \\
\hline Dependence on partner & 54.9 & 32.3 & 6.0 & 6.8 & 0.0 & 14.9 & 20.0 & 33.2 & 28.9 & 2.1 & 0.9 \\
\hline $\begin{array}{l}\text { High cost of compliance } \\
\text { with donor's require- } \\
\text { ments }\end{array}$ & 35.7 & 56.6 & 4.3 & 1.7 & 1.7 & 8.5 & 21.3 & 25.5 & 36.2 & 6.8 & 1.7 \\
\hline \multicolumn{12}{|c|}{ Category - Grant Risk (Recognized by $61.0 \%$ ) } \\
\hline $\begin{array}{l}\text { Considerable delays in } \\
\text { tranche disbursement }\end{array}$ & 15.3 & 34.9 & 12.3 & 20.4 & 17.0 & 4.3 & 4.3 & 32.3 & 48.9 & 8.9 & 1.3 \\
\hline $\begin{array}{l}\text { Lack of necessary } \\
\text { knowledge and skills to } \\
\text { utilized the awarded grant }\end{array}$ & 66.4 & 20.0 & 8.5 & 5.1 & 0.0 & 14.0 & 11.1 & 28.9 & 38.3 & 6.4 & 1.3 \\
\hline $\begin{array}{l}\text { Changes in environment } \\
\text { preventing organization } \\
\text { from utilizing the award- } \\
\text { ed grant }\end{array}$ & 24.3 & 64.7 & 4.7 & 6.4 & 0.0 & 8.9 & 15.3 & 20.4 & 48.5 & 5.5 & 1.3 \\
\hline Undervalued contract & 31.1 & 48.9 & 14.9 & 5.1 & 0.0 & 6.4 & 17.9 & 35.3 & 35.7 & 4.3 & 0.4 \\
\hline
\end{tabular}


Table 1. Risk Categories in Nonprofit Organizations, cont.

\begin{tabular}{|l|c|c|c|c|c|c|c|c|c|c|c|c|}
\hline \multirow{2}{*}{$\begin{array}{c}\text { Risks } \\
\text { in Nonprofit } \\
\text { Organization }\end{array}$} & $\begin{array}{c}\text { Unlike- } \\
\text { ly }\end{array}$ & $\begin{array}{c}\text { Possi- } \\
\text { ble }\end{array}$ & $50 / 50$ & Likely & $\begin{array}{c}\text { Nearly } \\
\text { Certain }\end{array}$ & $\begin{array}{c}\text { Insig- } \\
\text { nificant }\end{array}$ & Minor & $\begin{array}{c}\text { Moder- } \\
\text { ate }\end{array}$ & Major & $\begin{array}{c}\text { Don't } \\
\text { Critical } \\
\text { know/ } \\
\text { hard to } \\
\text { tell }\end{array}$ \\
\cline { 2 - 16 } & $(\%)$ & $(\%)$ & $(\%)$ & $(\%)$ & $(\%)$ & $(\%)$ & $(\%)$ & $(\%)$ & $(\%)$ & $(\%)$ \\
\hline \multicolumn{7}{|c|}{ Category - Personnel/Volunteers Risk (Recognized by 55.3\%) } \\
\hline $\begin{array}{l}\text { Volunteer/ employee will } \\
\text { sustain injury at work }\end{array}$ & 11.1 & 76.2 & 8.9 & 3.8 & 0.0 & 11.1 & 17.4 & 42.6 & 23.4 & 4.3 & 1.3 \\
\hline $\begin{array}{l}\text { Volunteer/ employee will } \\
\text { cause the organization's } \\
\text { client's injury }\end{array}$ & 42.1 & 51.1 & 6.8 & 0.0 & 0.0 & 11.1 & 15.7 & 31.5 & 34.9 & 5.5 & 1.3 \\
\hline $\begin{array}{l}\text { Volunteer/ employee will } \\
\text { harm the reputation of } \\
\text { organization }\end{array}$ & 23.8 & 67.7 & 6.4 & 2.1 & 0.0 & 11.5 & 6.4 & 35.3 & 40.9 & 4.7 & 1.3 \\
\hline \begin{tabular}{l} 
High staff turnover \\
\hline
\end{tabular} & 30.6 & 59.6 & 6.8 & 3.0 & 0.0 & 13.6 & 15.7 & 43.4 & 22.6 & 3.0 & 1.7 \\
\hline
\end{tabular}

Relative to major risk categories, the following question was asked: What are the risks taken by the organization? Respondents could tick all the categories that existed in their organization. The results are presented in Table 1 in lines against each major risk category.

The most frequently quoted risk category was the financial risk ( $76.6 \%$ of response). Meanwhile, the following risks were labeled as likely and nearly certain: dependence on a low number of sources of revenue (33.6\%), lack of financial liquidity $(24.3 \%)$, and inadequate investment policy $(22.1 \%)$. The following factors in this category have the biggest impact (major and critical level) on the organization: lack of financial liquidity (68.5\%), excessive indebtedness $(62.6 \%)$, use of funds against the intent of the donor/grantor (53.2\%), financial fraud $(52.8 \%)$, and inadequate maintenance of long-term sources of funding $(51.5 \%)$.

Polish non-governmental organizations are exposed to grant risk (61\% of response). The likelihood of occurrence is rated as "likely" and "nearly certain" for considerable delays in tranche disbursement by $37.4 \%$ of respondents. The other likelihoods have not exceeded $7 \%$ of response. With regard to the level of impact on organization, the risk of delayed tranche disbursement was also rated the highest with $57.9 \%$ of respondents pointing to "major" and "criti- cal." Respondents also stressed that changes in the environment may prevent the organization from using the grant $-54 \%$ of response.

For $55.3 \%$ of surveyed organizations, the risk related to staff and volunteers is crucial. However, the likelihood of occurrence of its different constituents was rated surprisingly low:

that is, only $3.8 \%$ of respondents believe that it was likely or nearly certain for an employee or a volunteer to sustain an injury at work.

A similar level is observed with operational risk. This risk is recognized by $54.6 \%$ of respondents. The most likely risk is that of an inadequately functioning fundraising system $(31.1 \%)$ and competition from other organizations (26.4\%). Inadequate fundraising scored the highest in terms of possible impact $(56.6 \%)$.

Finally, there is the cooperation or partnership risk (51.1\%). This significant risk category includes "likely" or "nearly certain" risks of overdependence on a partner $(6.8 \%)$, loss of reputation as a result of unethical conduct of the partner (5.5\%), high cost of compliance with donor's requirements (3.4\%), and loss of identity (1.3\%). The potential impact of these factors on the organizations is much strongly rated. 
"Major" or "critical" risks include loss of identity $(57 \%)$, loss of reputation as a result of unethical conduct of the partner (53.2\%), high cost of compliance with donor's requirements $(43 \%)$, and overdependence on a partner (31.1\% of respondents).

\section{$4 \quad$ Strategic Risk Management Process}

The present section serves the verification of the strategic risk management model which is being recommended for the nonprofit organization and spread by the American association The Nonprofit Risk Management Center. The presented research findings will allow to determine the degree of implementation of the proposed model in the Polish nonprofit organizations and to respond to the research question whether nonprofit organizations manage risk in a strategic way?

The risk management process can be defined as a systematic and purposeful sequence of activities including "Identifying the context," that is, profiling the organization in risk management and setting risk management objectives; "Risk assessment," that is, risk identification and prioritization; "Taking and communicating appropriate decisions;" "Acting on decisions taken;" and "Monitoring and adjustment" (Head, Herman, 2002, pp. 47).

Respondents were asked whether they "see any sense or need for risk management in their organizations." Thirty-four percent said they believed so and 31.1.\% stated the opposite; $26.4 \%$ said "definitely" and $2.1 \%$ said "definitely not;" $6.4 \%$ did not have an opinion. In conclusion, a vast majority of Polish nongovernmental organization (60.4\%) see a need for risk management.

Respondents were asked whether their organizations took any risk management measures. A majority (53.2\%) said they did not but $46.8 \%$ admitted they did.

There was a similarly dissatisfactory response to the question "Is your organization planning to introduce risk management?" Only 10.4\% said they had such plans but $44.8 \%$ said they did not and the same percentage did not have an opinion. This question was dedicated only to those respondents who said they engaged in no risk management. The following question was answered by 110 individuals from organizations that engaged in risk management or were planplanning to do so. The purpose of the question was to identify measures from a verified risk management process. The results are summarized in Fig. 1.

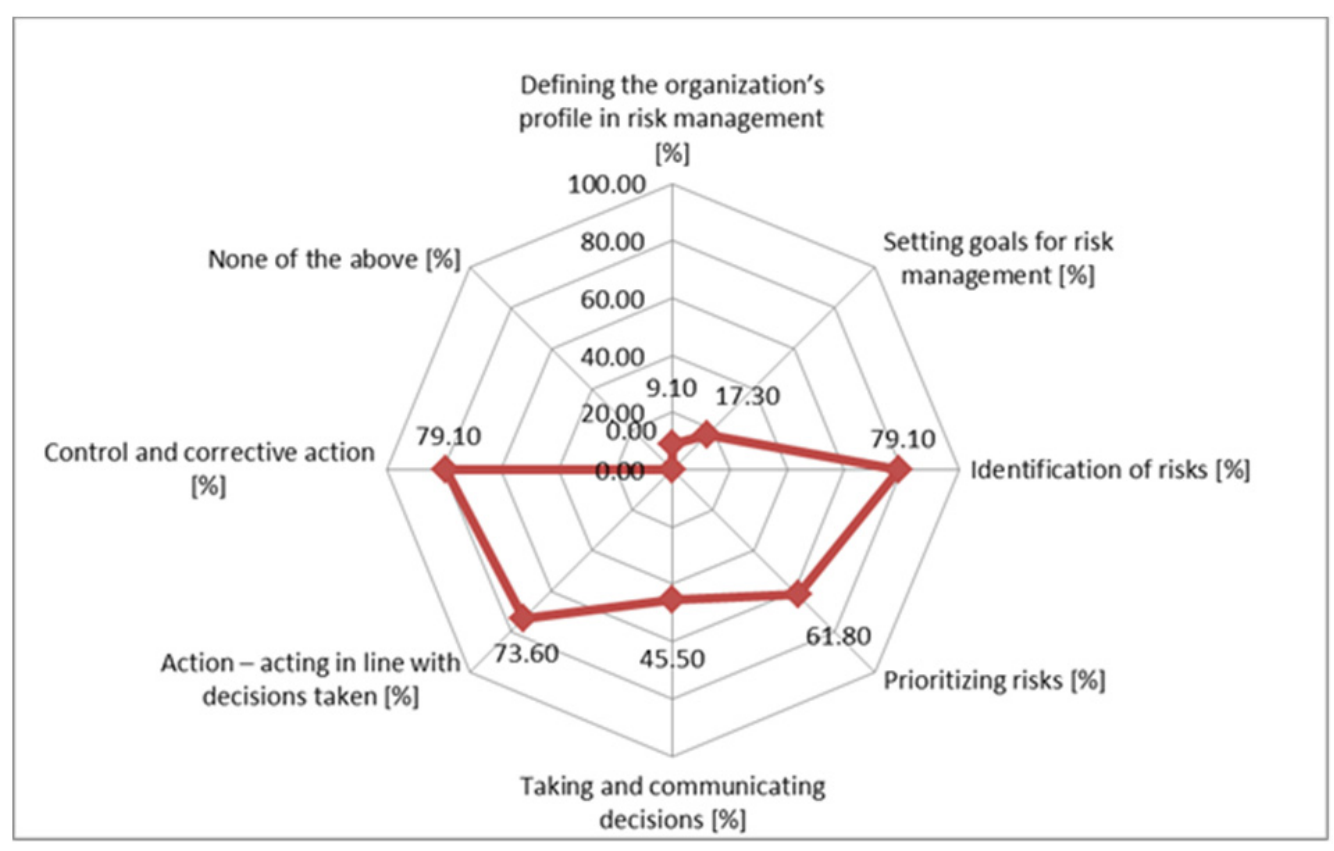

Figure 1. Implementing a risk management process. Which of the following actions that make up the risk management process are taken in your organization? Tick all actions taken $(\mathrm{N}=110)$ 
The most frequent types of risk management activities are risk identification (79.1\% of response) and monitoring and adjusting (79.1\% of response). A slightly lower percentage of organizations (73.6) stated that they followed up on the decisions they had made. An even lower percentage (61.8) prioritizes their risks. Only $45.5 \%$ pointed to the decision making and communicating step. Very few organizations set risk management objectives (17.3\%) and identify the profile of the organization in risk management $(9.1 \%)$. The heterogeneity of the results suggests that only few organizations have implemented the proposed risk management model in its entirety. Instead, they focus on the operational parts of the model with risk assessment, mitigation, and monitoring. They skip the initial steps in the process because they fail either to understand their importance or to appreciate their relevance.

\subsection{Defining the Context}

Nonprofit organizations should start a risk management process by engaging in a detailed review of their history, culture, and past activities in order to increase the chances of success and to identify adequate funds for future activities. Defining the context or contextualization means analyzing the environment and identifying the normal or routine state of the organization and the target position it wants to achieve in the future. The context is the baseline for the goals and objectives of the organization, the implementation of which will be hindered by unexpected future events that will be subject to the strategic management process. While defining the context, the organization may want to answer questions regarding the history of risk management in the organization, propensity to engage in risk management, reaction of staff, and division of responsibilities in the process (Head, Herman, 2002, pp.48-49). The response to these questions will help develop the profile of the organization, which will be instrumental when the organization develops the various decision steps of the risk management process. Further, it will help define the objectives for the system implementation.

This research project asked a series of questions regarding this stage of the strategic risk management. The answers will assist defining the prevailing profile of Polish nonprofit organizations in risk management. The three following questions were answered by organizations that do not engage in risk management now but are planning to do so in the future.

Organizations in the sample were asked: "How is the staff likely to react to the announced launch of a risk management program in your organization?" The responses suggest the reaction would be "fairly positive" (76.9\%), "definitely positive" (7.7\%), and "neither positive nor negative (15.4\%). A high percentage of respondents $(92.3 \%)$ believed that it would be possible to find people in their organizations who would be willing to join a risk management team.

Table 2. Attitudes to risk management $(\mathrm{N}=110)$

\begin{tabular}{|l|c|c|c|c|c|}
\hline \multicolumn{1}{|c|}{ Attitude } & $\begin{array}{c}\text { Definitely } \\
(\%)\end{array}$ & $\begin{array}{c}\text { I think so } \\
(\%)\end{array}$ & $\begin{array}{c}\text { Hardly ever } \\
(\%)\end{array}$ & $\begin{array}{c}\text { Definitely not } \\
(\%)\end{array}$ & $\begin{array}{c}\text { Hard to tell } \\
(\%)\end{array}$ \\
\hline $\begin{array}{l}\text { I willingly support the implemen- } \\
\text { tation of risk management pro- } \\
\text { gram bearing in mind both the risk } \\
\text { of increase and decrease }\end{array}$ & 21.8 & 56.4 & 9.1 & 0.9 & 11.8 \\
\hline $\begin{array}{l}\text { It assumes the role of program } \\
\text { sponsor }\end{array}$ & 10.0 & 56.4 & 14.5 & 0.0 & 19.1 \\
\hline I delegate it to subordinates & 1.8 & 35.5 & 38.2 & 9.1 & 15.5 \\
\hline $\begin{array}{l}\text { I am inclined to become personally } \\
\text { involved in risk management }\end{array}$ & 20.9 & 68.2 & 2.7 & 0.9 & 7.3 \\
\hline
\end{tabular}


The planned risk management will cover the entire organization in $84.6 \%$ of cases, and in $15.4 \%$ of cases, it will be limited to one part of the operations.

The following question regarded the attitudes to risk management among the leaders of the organizations. Results are summarized in Table 2

The results reveal that such attitudes presented by leaders of the interviewed nonprofit organizations are satisfactory and have a positive effect on the efficiency of the risk management system.

The following questions further explored the detailed context of Polish nonprofit organization in risk management. Where implemented, the risk management system covers the entire organization $(90.9 \%$ of cases) versus a limited part of the operations only in $9.1 \%$ of cases. The risk management area is the responsibility of more than one person ( $77.3 \%$ claim more than one person is responsible). Of the 25 organizations which stated otherwise, the responding individual was the responsible person in $60 \%$ of cases and a different board member in $40 \%$ of cases.

\subsection{Risk Assessment}

Risk assessment is a step where a portfolio of risks is identified and then each of them is assessed in terms of value or importance. First, it makes sense to appoint a Risk Management Committee within the organization. Such a team should be made up not only of executive board members but also of individuals directly involved in tasks and projects. The first responsibility of the Committee should be to develop a list of clearly defined risks or future events that may be different from those for which the organization is routinely prepared. Such a list may include specific programs, planned events, and the overall operations of the organization, its goals, and objectives and changes in the environment which may affect it.

Alternatively, risks can be classified according to the client segment, for example, youth program risks and senior programs risks. While developing the list, organizations may use risk categories presented in this article.

The second task of the Committee is to prioritize the risks. Two basic criteria can be applied: "Frequency" or how often can the risk happen?; and "Importance" or what cost or benefit may be expected if the risk happens?

Organizations that have not focused on recording their risks may experience problems in accurately assessing the future events. Instead, a scoring method can be used with frequency and importance presented on a scale of 1-10. Dorminey and Mohn (2007) suggested using a descriptive scale and risk assessment in terms of likelihood and impact.

A ranking list of identified risks structured according to likelihood and importance will allow the organization to take appropriate decisions to reduce a potential loss or take advantage of possible profits.

When asked "Has the organization ever made an attempt to identify risks?" $53.2 \%$ of organizations said "Yes." In $48.8 \%$ of cases, risk identification (out of 125 organizations which answered the previous question positively) has been conducted in a structured and informed manner; $20 \%$ cannot make up their mind. Organizations that identify risks in a structured and informed manner $(\mathrm{N}=61)$ do it more often than once in a year (59\% of response), once in a year on an average (37.7\% of response). Risk identification is conducted by the leader of the organization or other members of the executive or management board (a total of $68.8 \%$ of response), oversight and audit bodies ( $23 \%$ of response), and lower level managers (4.9\% of response). Results of risk identification are not documented in $60.7 \%$ of organizations as opposed to $34.4 \%$ of organizations that do, and $4.9 \%$ of organizations provided no clear reply to the question.

In $70.5 \%$ of cases, Polish nonprofit organizations assess the identified risks in terms of the likelihood of their occurrence. This is not the approach of $23 \%$ of respondents, and $6.6 \%$ of respondents have no opinion. Similarly, risks are assessed for importance by $73.8 \%$ of respondents. 


\subsection{Making and Communicating the Decision and Action}

There are many effective risk management techniques that can be applied to address specific identified risks. A number of nonprofit organizations use those techniques often now knowing that what they do is part and parcel of strategic risk management. Head and Herman (2002, pp.55-63) provided an exhaustive list of such techniques which includes provision of training, securing OHS tools and equipment, staff appraisals, volunteer and participant assessment, adequate supervision, maintenance and repair planning, contingency planning and testing, clearly defining expectations and issuing clear instructions, use of external experts, stocktaking of assets, regulatory compliance, internal audit procedures, readiness to cover financial losses, and regular stakeholder communication.

The stage of the risk management processes called "Action" covers the implementation of actions defined earlier in line with the logical sequence as defined in the strategic risk management plan.
It is important that actions should be implemented by individuals who were previously involved in planning the actions and identifying risks. This should improve the chances for success. While performing the tasks, one should rely on trust and premonition, but more importantly, one should make sure that all the steps are adequate. When partnering with other organizations, it is advisable to have written arrangement defining the mutual scope of responsibility and accountability.

When asked whether their organizations used potential risks while implementing their objectives, $52.5 \%$ of respondents $(\mathrm{N}=61)$ replied positively, $37.7 \%$ replied negatively, and $9.8 \%$ were neutral.

Respondents $(\mathrm{N}=235)$ were asked the following question: To what extent do you believe your organizations complies with regulations in the area of health and safety, fire protection, sanitary protection, and education (as the case may be depending on the type of organization)? Prevailing responses are "very high" compliance, $37.4 \%$, and "high", $34.0 \%$.

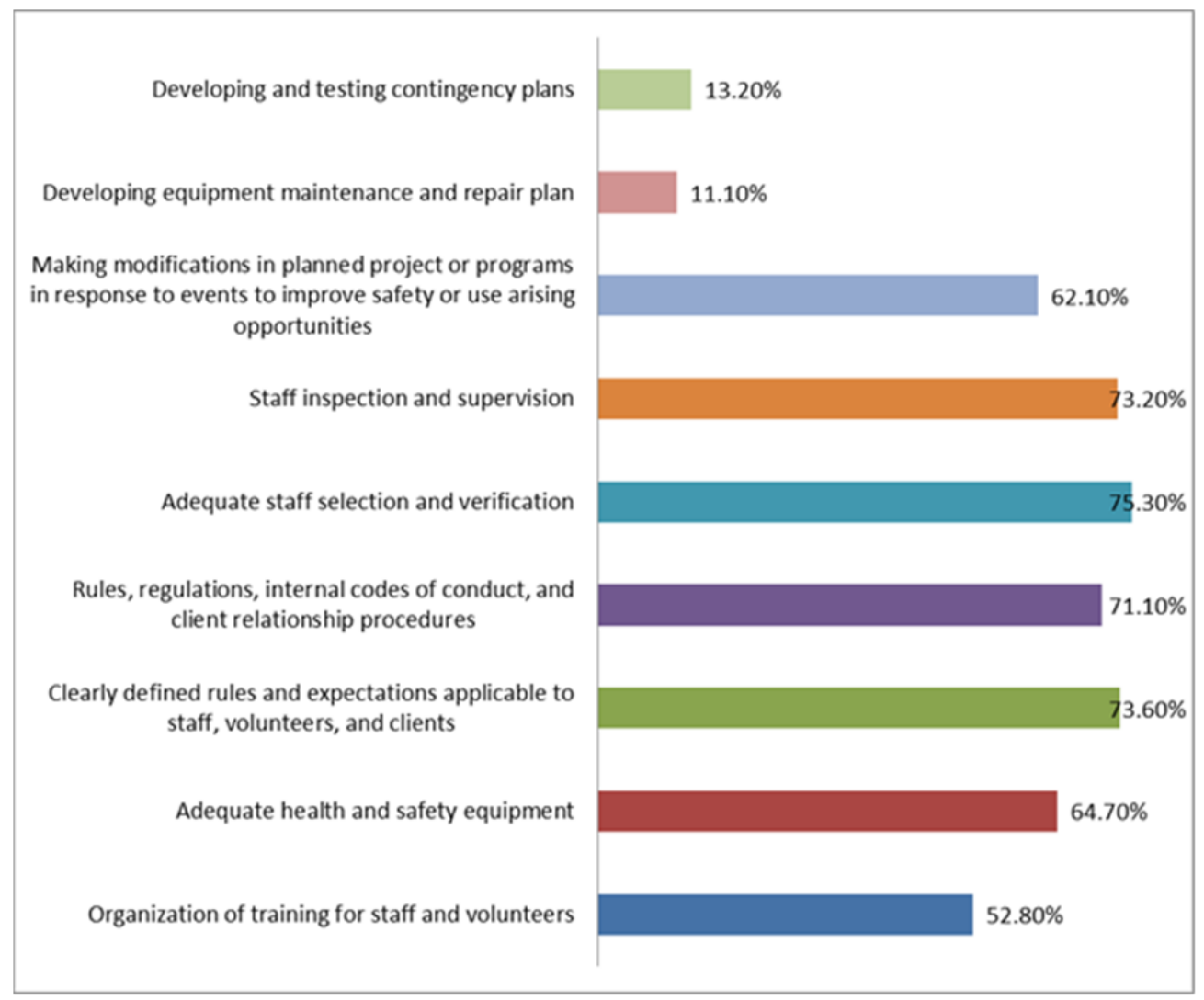

Figure 2. Risk management techniques. Does your organization use any of the following techniques to reduce risk? Tick all if used $(\mathrm{N}=235)$ 
Unfortunately, as many as $62.1 \%$ of surveyed organizations are not ready to cover financial losses. Only $37.9 \%$ admit that they are possibly prepared to do so. This demonstrates how financially vulnerable the third sector is in Poland, and it should be seen as yet another stimulus for implementing a risk management system.

A vast majority of organizations engage in regular communications with stakeholders to reduce risk (73.6\% of response).
A series of other techniques have been tested for potential relevance for risk management. Fig. 2 summarizes the results.

Nearly all the listed risk mitigation techniques have been used by nonprofit organizations. The respondents were equally positive about the frequency of behaviors in their organizations they believed should occur in a well-functioning risk management system. Table 3 presents the results.

Table 3. Frequency of behaviors in the risk management process $(\mathrm{N}=235)$

\begin{tabular}{|l|c|c|c|c|c|}
\hline \multirow{2}{*}{$\begin{array}{l}\text { Please state how often the following behaviors occur in your organ- } \\
\text { ization }\end{array}$} & Never & Rarely & $\begin{array}{c}\text { Some- } \\
\text { times }\end{array}$ & Often & $\begin{array}{c}\text { Don't } \\
\text { know/ } \\
\text { hard } \\
\text { to tell }\end{array}$ \\
\cline { 2 - 5 } & $(\%)$ & $(\%)$ & $(\%)$ & $(\%)$ & $(\%)$ \\
\hline Decisions taken to reduce risk are turn into actions & 3.0 & 6.4 & 31.1 & 55.7 & 3.8 \\
\hline Actions are taken by the person who participated in planning & 2.1 & 4.3 & 19.6 & 71.1 & 3.0 \\
\hline $\begin{array}{l}\text { There is a conscious and informed process to monitor the actions } \\
\text { taken }\end{array}$ & 0.4 & 3.4 & 14.0 & 77.0 & 5.1 \\
\hline $\begin{array}{l}\text { The organization uses external experts/professionals (accounting, } \\
\text { legal, OHS, etc.) }\end{array}$ & 6.4 & 13.6 & 31.5 & 46.8 & 1.7 \\
\hline $\begin{array}{l}\text { The is a process to take stock of assets } \\
\text { Superiors clearly communicate their expectations and instruct per- } \\
\text { sonnel }\end{array}$ & 2.1 & 4.7 & 17.4 & 73.6 & 2.1 \\
\hline
\end{tabular}

Informed and purposeful inspection of activities has received the highest rating $(77 \%)$ in the surveyed organization; $73.6 \%$ admit to have clearly and precisely formulated expectations of and instructions to subordinates and $71.1 \%$ of respondents claim that activities are carried out by those who involved in planning in their organizations.

\subsection{Monitoring and Course Correcting}

This step is designed to monitor the strategic risk management process and to implement necessary corrections. It is critical that a developed action plan should not be seen a static, once-for-all document. The environment of nonprofit organizations is subject to constant change. New risks emerge as quickly as certain existing ones become obsolete. Activities planned to mitigate the risk of underperformance in a project may prove insufficient at a later stage as a new threat becomes apparent. If an organization is not ready to correct its existing plan, it may be deprived of chance to benefit from the opportunities in its environment.

The results presented in Table 3 reveal that $77 \%$ of the surveyed organizations often take informed and purposeful measures to monitor their activities and $14 \%$ do it from time to time. Internal audit procedures are present in $75.7 \%$ organizations and only $24.3 \%$ of organizations have not developed them in writing. Of all organizations that apply this technique $(\mathrm{N}=178), 79.2 \%$ have an internal audit function as 
opposed to $20.8 \%$, which have other controls that have remained unidentified in this study.

Furthermore, respondents were asked about their perceived efficiency (performance) of the measures taken as part of the risk management process. A relatively large group (64.3\%) of respondents believe the efficiency is fairly high and $15.3 \%$ think it is very high; $17 \%$ think it is neither high nor low, in both cases, $0.9 \%$ view it is low or very low; $1.7 \%$ of respondents did not have an opinion.

\section{Conclusions}

Similar to their commercial counterparts, not-forprofit (non-governmental) organizations should focus more on the risks they are exposed to. Needless to say, risk identification, risk assessment, taking advantage of risk, or risk prevention contribute to improved quality of management and higher efficiency in any organization. Meanwhile, existing research and concepts developed by management sciences in Poland or internationally have not fully addressed the needs of managers in nonprofit organizations. This present paper is an attempt at filling the research gap at least to some degree.

In response to the research question, a comprehensive classification of risks faced by nonprofit organizations is proposed and it includes risks related to management, operation, finance, external environment, regulatory environment, partnership, grants, and staff/volunteers. The findings of this study appear to validate this classification as each of the risk areas was quoted by at least $24 \%$ of respondents. The most frequent types of risks are the financial, grant, staff/volunteers, operational, and partnership risks. Interestingly enough, respondents tend to believe in a relatively low probability of these risks actually materializing in their organizations. In contrast, they tend to appreciate their strong potential impact on their operations. One may wonder whether this is caused by the irrelevance of the proposed risk categories. The answer is hardly positive as the perceived impact is high. Is it fair to say that organi-zations fail to see the possibility of those risks becoming reality in their immediate or remote vicinity or inside their organizations? It could also be claimed that their awareness of the possible risks they may be vulnerable to is weak and that this is caused by the lack of expertise, lack of access to available information, or not enough commitment from the research community to study risk management in nonprofit organizations. Future research may choose to test the validity of this claim.

The emerging picture of strategic risk management in Polish nonprofit organization is all but clear. Note that only $47 \%$ of organizations take any measures whatsoever to strategically manage their risks. On the other hand, organizations that do not do that do use risk management techniques to minimize risk and their decision-making process is adequate in this respect.

A vast majority of organizations that take risk management measure identify risks and assess them in terms of their importance and probability of occurrence. They mitigate risk by using a spectrum of management techniques, monitor performance, and adapt if necessary.

However, the first stage of the presented strategic risk management model, that is, contextualization, is the least operationalized. Contextualization is about identifying the profile of the organization and risk management objectives. Hence, organizations fail to engage in self-assessment and goal setting. This leads to vital questions: Is the risk management in Polish nonprofit organizations strategic? Do Polish nonprofits engage in strategic risk management? In the light of many studies (Bryson, 1988; Chandler, 1962) that stress the primacy of planning and goal setting in strategic management, the answers must be negative! Wherever Polish nonprofit organizations manage their risks, they do not do it in a strategic manner. This observation may open up new research on strategic risk management in the third sector. It could be asked if the same pattern prevails in other countries, what are its root causes and implications for management theory and practice.

It is also possible to subject the number of other issues concerning the risk management in nonprofit organizations to the future researches. It seems that it is possible to subject the sensitivity to the risk of these subjects to deeper analysis. It may be noted that it depends on internal factors (e.g., resulting from their inherent differences from the sector for- 
profit, including lack of the equity) and from external factors (e.g., legal regulations specific to each country).

Undoubtedly, the growing third sector deserves more research attention to develop and disseminate more effective solutions, thus bringing the management of this socially crucial segment of economy to a higher level.

\section{References}

[1] Bowman, W., Keating, E., Hager, M.A., 2007. Investment Income. In: Financing nonprofits, putting theory into practice, edited by $\mathrm{D}$. R. Young. Lanham: National Center on Nonprofit Enterprise and Rowman and Littlefield Publishers, INC.

[2] Bryson, J.M., 1988. A strategic planning process for public and non - profit organizations. Long Range Planning, 21 (1), pp.73-81.

[3] Chandler, A.D., 1962. Strategy and structure: Chapters in the history of the American industrial enterprise. Cambridge: MASS, MIT Press.

[4] Christensen, R.K., Clerkin, R.M., Nesbit, R., Paarlberg, L.E., 2009. Light and dark sides of nonprofit activities and the rules to manage them: The case of charitable bingo. Administration \& Society, 41 (2), pp.213 - 234.

[5] Clary, D.H., 1997. Six steps to good-reputation insurance. Nonprofit World, 15 (1), pp.45-47.

[6] Domański, J., 2012. Competitiveness of nongovernmental organizations in developing countries: Evidence from Poland. Nonprofit and Voluntary Sector Quarterly, 41 (1), pp.100-119.

[7] Domański, J., 2014. Zarzqdzanie ryzykiem w organizacjach non profit (Risk Management in Nonprofit Organizations). Warszawa: Wolters Kluwer.

[8] Dorminey J., Mohn R., 2007. A model for notfor-profit enterprise risk management: ERM at the federal reserve bank of Richmond. Journal of Government Financial Management, 56 (1), pp.50-57.

[9] Duncan, N.K., 2008. Risk management: How to protect your assets? Nonprofit World, 26 (1), pp.25-28.
[10] Fast, L., 2007. Characteristics, context and risk: NGO insecurity in conflict zones. Disasters, 31 (2), pp.130-154.

[11] Greenlee, J.S., Tuckman, H., 2007. Financial health. In: Financing nonprofits, putting theory into practice, edited by D.R. Young. Lanham: National Center on Nonprofit Enterprise and Rowman and Littlefield Publishers, INC.

[12] Gumkowska, M., Herbst, J., 2008. Najważniejsze pytania - podstawowe fakty. Polski sektor pozarządowy 2008 (Key Questions - Basic Facts. Polish Nongovernmental Sector in 2008).Warszawa: Stowarzyszenie Klon/Jawor.

[13] Head, G.L., Herman, M.L., 2002. Enlightened risk taking, A guide to strategic risk management for nonprofit. Washington: Nonprofit Risk Management Center.

[14] Iwankiewicz-Rak, B., 2006. Siła wizerunku organizacji pozarzadowej (The Power of the Nongovernmental Organization's Image). Trzeci Sektor, 5, pp.30-36.

[15] Jackson, R.A., 2008. Reputations at RISK. Internal Auditor, 65 (3), pp.64-70.

[16] Kearns, K., 2007. Income portfolios. In: Financing nonprofits, putting theory into practice, edited by D. R. Young. Lanham: National Center on Nonprofit Enterprise and Rowman and Littlefield Publishers, INC.

[17] Krzelowska, M.I., 2008. Sukces organizacji pożytku publicznego w świetle badan. (The Success of Public Benefit Organizations in Light of Research). Trzeci Sektor, 13, pp.68-75.

[18] Lehn, M.B., 2008. Bearing more risk for results: Performance accountability and nonprofit relational work. Administration \& Society, 39 (8), pp.959-983.

[19] Mallin, M.L., Finkle, T.A., 2007. Social entrepreneurship and direct marketing. Direct Marketing: An International Journal, 1 (2), pp.6877.

[20] Martínez, C.V., 2003. Social alliances for fundraising: How Spanish nonprofits are hedging the risks. Journal of Business Ethics, 47 (3), pp.209222.

[21] Mitchell, V., 1995. Assessing the perceived risks associated with appointing planning consultants. 
Journal of Marketing Management, 11 (1-3), pp.165-186.

[22] Mu-Sheng Chang., 2008. Alternative risk transfer: Evidence of self-insurance among hospitals in Pennsylvania for workers' compensation liability. Journal of Insurance Regulation, 27 (2), pp.59-94.

[23] Pike, S., Roos, G., Marr, B., 2005. Strategic management of intangible assets and value drivers in $\mathrm{R} \& \mathrm{D}$ organizations. $R \& D$ Management, 35 (2), pp.111-124.

[24] Sharp, Z., Brock, D.M., 2012. Implementation through risk mitigation: Strategic processes in the nonprofit organization. Administration \& Society, 44 (5), pp.571-594.

[25] Sollis, P., 1995. Partners in development? The state, nongovernmental organizations and the UN in Central America. Third World Quarterly, 16 (3), pp.525-542.

[26] Stewart, L.J., Owhoso, V., 2004. Derivative financial instruments and nonprofit health care providers. Journal of Health Care Finance, 31 (2), pp.38-52.

[27] Stewart, L.J., Trussel, J., 2006. The use of interest rate swaps by nonprofit organizations: Evidence from nonprofit health care providers. Journal of Health Care Finance, 33 (2), pp.6-22.

[28] Trussel, J.M., Patrick, P.A., 2009. An empirical analysis of financial distress in Pennsylvania hospitals. Journal of Health Care Finance, 36 (1), pp.31-60.

[29] Tyminshi, R., 1998. Reducing funding risk and implementing a fundraising plan: A case study. Nonprofit Management \& Leadership, 8 (3), pp.275-287.

[30] Tyrakowski, M., 2007. Rola organizacji pozarządowych w rozwiązywaniu problemów społecznych (The Role of Non-Governmental
Organizations in Solving Social Problems). Znacznie-ZNZE WSIiZ, 2 (4), pp.124-151.

[31] Waśkowski, Z., 2008. Uwarunkowania i formy współpracy między organizacjami non profit a podmiotami komercyjnymi na rynku kultury (Terms and Conditions of Partnerships Between Nonprofit and Commercial Organizations in the Culture Market). Świat Marketingu.

[32] West, D.C., Sargeant, A., 2004. Taking risks with advertising: The case of the not-for-profit sector. Journal of Marketing Management, 20 (9), pp.1027-1045.

[33] Wymer Jr., W.W., Samu, S., 2003. Dimensions of business and nonprofit collaborative relationships. Journal of Nonprofit \& Public Sector Marketing, 11 (1), pp.3-22.

[34] Yan, W., Denison, D.V., Butler, J., 2009. Revenue structure and nonprofit borrowing. Public Finance Review, 37 (1), pp.47-67.

[35] Yetman, R.J., 2007. Borrowing and dept. In: Financing nonprofits, putting theory into practice, edited by D. R. Young. Lanham: National Center on Nonprofit Enterprise and Rowman and Littlefield Publishers, INC.

[36] Young, D.R., 2007. Toward a normative theory of nonprofit finance. In: Financing nonprofits, putting theory into practice, edited by $\mathrm{D}$. R. Young. Lanham: National Center on Nonprofit Enterprise and Rowman and Littlefield Publishers, INC.

[37] Young, D.R., 2009. How nonprofit organizations manage risk? In: Paid and unpaid labour in the social economy. edited by S. Destefanis, \& M. Musella. AIEL Series in Labour Economics, Physica-Verlag Heidelberg.

[38] Zapadka, P., 2007. Ryzyko prawne w działalności banków komercyjnych - wybrane zagadnienia (Legal risk in commercial banks - selected issues). Prawo Bankowe, 3 (115), p.30. 